\title{
Climatic control of fluvial-lacustrine cyclicity in the Cretaceous Cordilleran Foreland Basin, western United States
}

\author{
CARL N. DRUMMOND, * BRUCE H. WILKINSON† and KYGER C. LOHMANN† \\ *Department of Geosciences, Indiana University Purdue University, Fort Wayne, Fort Wayne, \\ IN 46805-1499, USA (drummond@smtplink.indiana.ipfw.edu) \\ tDepartment of Geological Sciences, The University of Michigan, Ann Arbor, MI 48109-1063, USA
}

\begin{abstract}
Tectono-stratigraphic models of foredeep sedimentation have generally presumed a direct link between changing rates of tectonism and concomitant sedimentological response as manifested by change in thickness, composition or depositional environment of sediment accumulating in adjacent basins. Lacustrine limestone units within the early Cretaceous fluvial/lacustrine Gannett Group of western Wyoming exhibit systematic variation in several geochemical proxies of relative rates of precipitation and evaporation, indicating that lakewater chemistry was controlled by variation in regional climate.

Change in proportion of allochthonous terrigenous clastic vs. autochthonous carbonate deposition, as well as carbonate $\mathrm{Mg} / \mathrm{Ca}$ ratio and stable isotopic composition, occurs at two scales. Metre-scale alternation of micritic limestone and argillaceous marl is accompanied by mineralogical and isotopic variation within individual beds, indicating preferential carbonate accumulation during intervals of decreased regional meteoric precipitation relative to lake-surface evaporation. Limestone deposition began during intervals of maximum aridity, and decreased as increased meteoric precipitation-driven flux of terrigenous clastic sediment overwhelmed sites of carbonate accumulation. Similar upsection variation in limestone mineralogy and isotopic composition at a scale of tens of metres reflects the multiple processes of long-term increase in meteoric precipitation and lakewater freshening prior to influx of terrigenous sediment, across-basin fluvial-deltaic progradation, and renewed accumulation of riverine terrigenous units. Such trends suggest that formation-scale alternation between fluvial clastic and lacustrine carbonate deposition was controlled by climate change.
\end{abstract}

\section{INTRODUCTION}

The stratigraphic architecture of foreland basin sequences has long been interpreted within a framework of sedimentary response to changing rate and magnitude of tectonism. In conventional tectono-stratigraphic models, deposition of coarse clastic wedges correlates with increased rates of basin subsidence and/or uplift of adjacent source regions, while deposition of fine-grained lacustrine or marine sediment is assumed to accompany decreased rates of basin subsidence and tectonic quiescence (Armstrong \& Oriel, 1965;
Armstrong, 1968; Wiltschko \& Dorr, 1983). As such, deposits of gravel wedges within late Mesozoic and Cenozoic synorogenic sequences of the Cordilleran foreland basin in Wyoming and Idaho have traditionally been attributed to source region uplift via episodic motion along thrusts within the Sevier orogenic belt. The presence of such coarse conglomeratic fluvial sediment is considered primary evidence for constraining estimates of the timing and duration of motion along those thrusts (Wiltschko \& Dorr, 1983).

An alternative tectono-stratigraphic model with presumed direct but inverse association between 


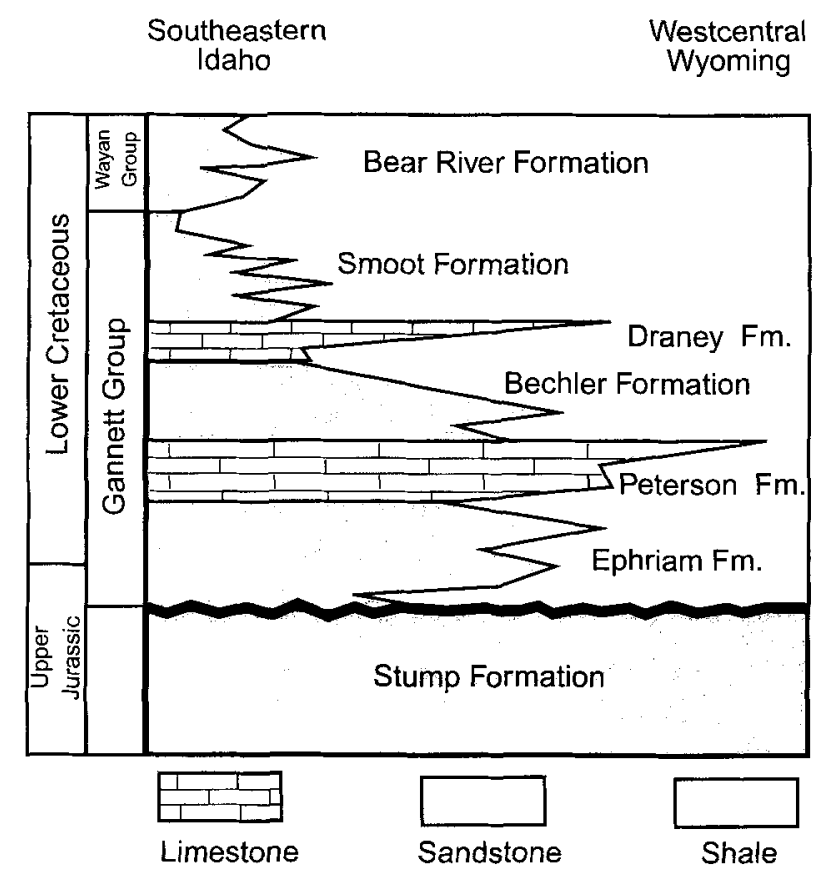

Fig. 1. Stratigraphic column of units exposed in southeastern Idaho and west-central Wyoming. The Lower Cretaceous Gannett Group is composed of two lacustrine and three fluvial formations, the lowest of which (the Peterson Limestone) represents initial deposition of continental sediment into the newly formed Cordilleran foreland basin. The Gannett Group lies unconformably above Upper Jurassic marine sandstones of the Stump Formation and conformably below Cretaceous marine sandstones and shales of the Bear River Formation. Modified from Glass \& Wilkinson (1980), Brown \& Wilkinson (1981) and Wanless et al. (1955).

clast size and fault motion has also been proposed by Beck \& Vondra (1985), Blair \& Bilodeau (1988) and Heller et al. (1988). Within this scenario, rapid subsidence during thrusting confines coarse sediment deposition to regions adjacent to the thrust (and associated development of lacustrine or marine systems along the basin axis), while intervals of tectonic quiescence allow for the progradation of coarse clastic material across the basin axis. Additionally, Flemings \& Jordan (1990) have shown that both progradational and retrogradational stratigraphic frameworks can be associated in time and space with episodic thrusting, and that specific characteristics within a particular basin vary as a function of patterns of tectonic load, flexure and sediment supply.

Regardless of specific relations between progradational portions of foreland basin sequences and timing of thrusting, deposition of formation-scale fluvial-lacustrine couplets within the lower Cretaceous Gannett Group of the western USA (Fig. 1) undoubtedly record alternation of rates of sediment supply and/or subsidence during initial phases of Sevier deformation. Inferred linkage between styles of sedimentation and intensity of tectonism is in general agreement with documented regional stratigraphic relations within the Gannett Group at a scale of individual fluvial and lacustrine formations. However, such an explanation presupposes that rate of sediment supply was solely controlled by tectonic uplift in the adjacent orogen, and that other factors related to denudation, such as climatically controlled variation in fluvial discharge, were less significant in altering sediment supply.

An alternative scenario for the development of foreland basin depositional cyclicity holds that orogenic uplift and/or basin subsidence may play a minor role in development of fluvial-tolacustrine depositional systems, and presumes that climate change, reflected as changing fluvial discharge and terrigenous clastic sediment delivery to basins of deposition, is the dominant factor controlling lateral and temporal lithological variation. A similar explanation of Cordilleran foreland basin depositional cyclicity has been proposed for younger marine units (Pratt, 1984; Arthur et al., 1985; Barron et al., 1985; Arthur \& Dean, 1991; Kirkland, 1991; Sethi \& Leithold, 1994). Here, rhythmic bedded limestone-shale couplets within the Turonian Greenhorn cycle have been interpreted to record episodic climate change during accumulation of shale-rich layers.

Regardless of the importance of tectonism and/or climate change in the generation of lithological cyclicity, fluvial to lacustrine transitions in foreland basin sequences must largely reflect the interplay between changes in rates of subsidence and change in rate of terrigenous sediment supply. Because elemental and isotopic compositions of lake systems are sensitive to variation in regional meteoric precipitation relative to evaporation in lake basin drainages, the lithological, mineralogical and geochemical composition of authigenic carbonate within lacustrine units of the Gannett Group potentially contain an excellent record of climate change in western North America during the early Cretaceous.

Such an interpretation of episodic climate change controlling the secular distribution of lacustrine deposition is certainly not new. Olsen (1986) used facies-dependent ranking of inferred lakewater depths to calculate periodicities of sediment accumulation (that were generally equivalent to orbital forcing functions) within early Mesozoic rift sediment of eastern North America, and subsequent studies have more 
rigorously described Milankovitch-band frequencies of lake depth and area within these sequences (Kominz \& Bond, 1990; Kominz et al., 1991). Analogous investigations have documented the presence of thousand-year frequencies and presumably climate-driven oscillations within Cretaceous marine sediment as well (Fischer \& Schwarzacher, 1984; Ditchfield \& Marshall, 1989; Park \& Oglesby, 1991).

If fluvial-lacustrine cyclicity within the Gannett Group does reflect secular variation in regional climate, such change should also have influenced the flux of meteoric water via precipitation and inflow, as well as water flux from the basin via evaporation and outflow. In that mineralogical, trace elemental and isotopic variation in lacustrine sediment has been recognized as a potentially useful record of regional climate (Eugster \& Hardie, 1978; Talbot, 1990; Talbot \& Kelts, 1991), compositional trends within the Peterson Limestone (see below) may record the importance of Cretaceous climatic variation in south-eastern Idaho and west central Wyoming, as well as the degree to which resultant variation in fluvial discharge influenced formation-scale lithological cyclicity within the Gannett Group.

\section{GENERAL SETTING}

The Peterson Limestone is the lowest lacustrine formation within the Gannett Group, which consists of five terrestrial (three fluvial and two lacustrine) formations bracketed between late Jurassic marine units and latest early Cretaceous deltaic marine sandstone and shale (Fig. 1).

\section{Stratigraphy}

The Gannett Group represents the first continental sediment shed into the Cordilleran foreland basin formed by thrust loading during the Sevier orogeny. In ascending order, the five formations of the Gannett Group are the basal fluvial Ephriam Conglomerate, the lacustrine Peterson Limestone, the fluvial-fleodplain Bechler Formation, the lacustrine Draney Limestone and the Smoot Formation, a poorly exposed alluvial siltstone and shale (Eyer, 1964). Outcrops of the Gannett Group are similar to a sequence of foreland basin sediments that occurs to the north as the Kootenai Formation of western Montana (Stokes, 1952; Wanless et al., 1955; Peck, 1957; Peck \& Craig, 1962; Suttner, 1969; Holm et al., 1977).

Outcrops of the Draney and Peterson Limestones occur throughout the Overthrust Belt, and indicate carbonate accumulation in lake systems of considerable size $\left(15000\right.$ and $20000 \mathrm{~km}^{2}$, respectively; Glass \& Wilkinson, 1980; Brown \& Wilkinson, 1981). As such, any change in lakewater composition inferred from upsection variation in carbonate mineralogy or composition could reflect climate change at a regional scale.

\section{Depositional setting}

In order to document regional patterns of carbonate accumulation, 13 stratigraphic sections were measured throughout the Wyoming-Idaho Overthrust belt (Fig. 2). Because post-depositional uplift and erosion have removed the Peterson Limestone and coeval units along the western margin of the lake basin, measured outcrops record basin centre to eastern margin lake deposition.

Stratigraphic sections parallel and perpendicular to the basin axis record spatially and temporally discontinuous episodes of carbonate accumulation. In a context of spatial variation down the basin axis, relatively pure limestone is the principal component of stratigraphic sections north of the lake centre, while grey argillaceous marl and shale predominate to the south. This pattern is taken as evidence for a generally southern fluvial source of terrigenous sediment, an interpretation in agreement with palaeocurrent studies of coeval fluvial sediment that indicate south-to-north axial drainage within the foreland basin (Eisbacher et al., 1974; Hopkins, 1985). Sedimentary characteristics commensurate with palustrine deposition (e.g. Platt, 1989) only occur in the lower several metres of stratigraphic sections near transitions from underlying fluvial lithofacies.

\section{Petrology and palaeontology}

The Peterson Limestone consists of metre-scale interbeds of light grey to white micrite and grey to red calcareous shale. Limestones generally consist of homogeneous mudstone with rare soft-sediment deformation structures, indicating occasional slumping and transport of semiconsolidated sediment (Glass, 1980). Limestones are not varved, and generally lack any distinguishable sedimentary structures. Mineralogically, the micrites consist of generally subequal percentages of anhedral calcite and uniformly dispersed euhedral microdolomite $(5-15 \mu \mathrm{m})$. Although the amount of each component varies up section and throughout the outcrop area, all occur with near 


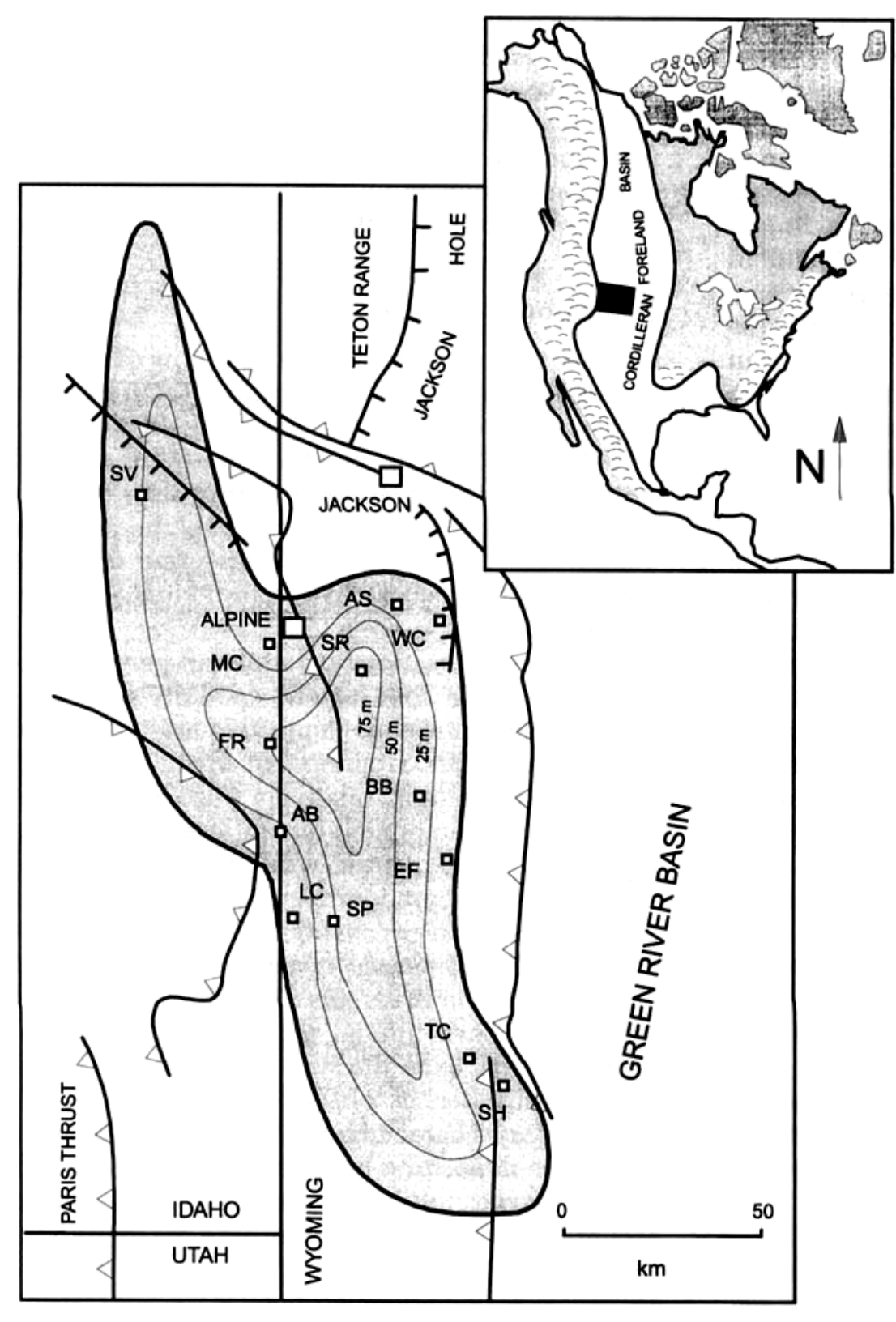

Fig. 2. Isopach map (contour interval $=25 \mathrm{~m}$ ) showing regional distribution of Peterson Limestone outcrops within the Overthrust belt of western Wyoming and south-eastern Idaho, and the location of 13 measured stratigraphic sections, SV=Swan Valley; MC $=$ McCoys Creek; $\mathrm{FR}=$ Freedom; $\mathrm{AB}=$ Auburn; $S P=$ Salt Creek Pass; $L C=$ Lost Creek; SR=Snake River; $\mathrm{AS}=$ Astoria $\mathrm{BB}=\mathrm{Blind}$ Bull Creek; $\mathrm{TC}=$ Turkey Creek; $\mathrm{SH}=$ Sheep Creek; $\mathrm{WC}=$ Willow Creek; $\mathrm{EF}=$ East Fork. Inset: location of the state of Wyoming relative to the Cordilleran foreland basin and the rest of North America. constant abundance within any hand sample (Drummond et al., 1993). Calcite composition as determined by X-ray diffraction (XRD) (e.g. Goldsmith et al., 1961) is typically $\mathrm{Ca}_{0.98} \mathrm{Mg}_{0.02} \mathrm{CO}_{3}$; dolomite is slightly calcian at $\mathrm{Ca}_{0.53} \mathrm{Mg}_{0.47} \mathrm{CO}_{3}$. Detailed mineralogical analysis of several stratigraphic sections indicates that dolomite compositions range from 0 to $100 \%$ of total carbonate. Completely calcitic micrites comprise over $20 \%$ of all samples, pure dolostone makes up $\approx 15 \%$, and the remaining $65 \%$ fall within a range of $10-60 \%$ dolomite (Fig. 3 ).

Fossil remains are generally small and rare, but include several varieties of charophytes and ostracodes (Eyer, 1964, 1969; Peck, 1957; Peck \& Craig, 1962). Macrofossils are uncommon but include Unio, Planorbis, Viviparus, Goniobasis and Physa (Mansfield, 1927, 1952). All taxa indicate deposition in nonmarine waters.

The depositional origin of the matrix micrite is difficult to determine due to textural disruption during diagenetic stabilization. However, the presence of abundant Chara fragments within calcite-rich beds indicates that at least some precipitation was driven by photosynthetic activity of aquatic macrophytes. Dolomite-rich beds are interpreted to have formed in more saline waters, probably through direct chemical sedimentation. 


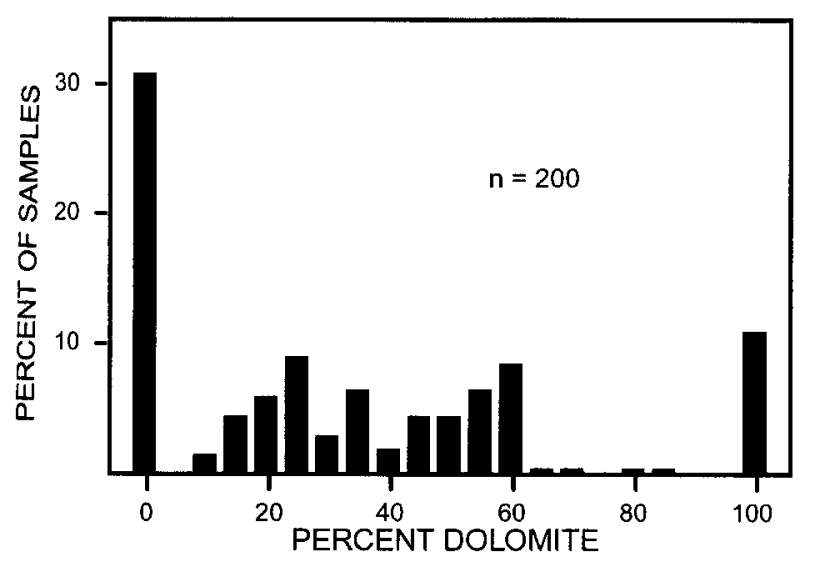

Fig. 3. Distribution of dolomite abundance within samples of micritic limestone. Note that the greatest proportion of Peterson units is calcitic limestone ranging in dolomite content up to about $60 \%$. Very few samples exhibit dolomite contents between this composition and that of pure dolostones.

\section{Carbonate geochemistry}

Geochemical analysis of the Peterson Limestone has centred on documenting lateral and stratigraphic variability in total carbonate content, dolomite/calcite ratio and stable isotopic composition within a context of observed limestone/ shale patterns discussed above. X-ray diffraction and stable isotopic analysis indicate that mineralogical and isotopic variability within hand samples is small compared with the magnitude of variability in a stratigraphic section. Replicate stable isotopic analyses of microgram-sized samples, taken from kilogram-sized handspecimens of micritic carbonate from several stratigraphic sections, demonstrate that $86 \%$ of all samples have less than $1 \%$ variance in $\delta^{18} \mathrm{O}$ and $90 \%$ have less than $0.5 \%$ variance in $\delta^{13} \mathrm{C}$ (Fig. 4).

In preparation for isotopic analysis, samples were placed in stainless-steel boats and roasted at $380^{\circ} \mathrm{C}$ under vacuum for $1 \mathrm{~h}$ to remove volatile contaminants. Samples were then placed in individual borosilicate reaction vessels and reacted at $72 \pm 2^{\circ} \mathrm{C}$ with three drops of anhydrous phosphoric acid for 12 min in a Finnigan 'Kiel' extraction system coupled directly to the inlet of a Finnigan MAT 251 isotope ratio mass spectrometer. Isotopic enrichments were corrected for acid fractionation and ${ }^{17} \mathrm{O}$ contribution (Craig, 1957) and are reported in per mil notation relative to the PDB standard. Precision was monitored with standards, bracketing the sample suite at the beginning, middle and end of each day's run. Measured precision was maintained at better than $0.1 \%$ for both carbon and oxygen isotope

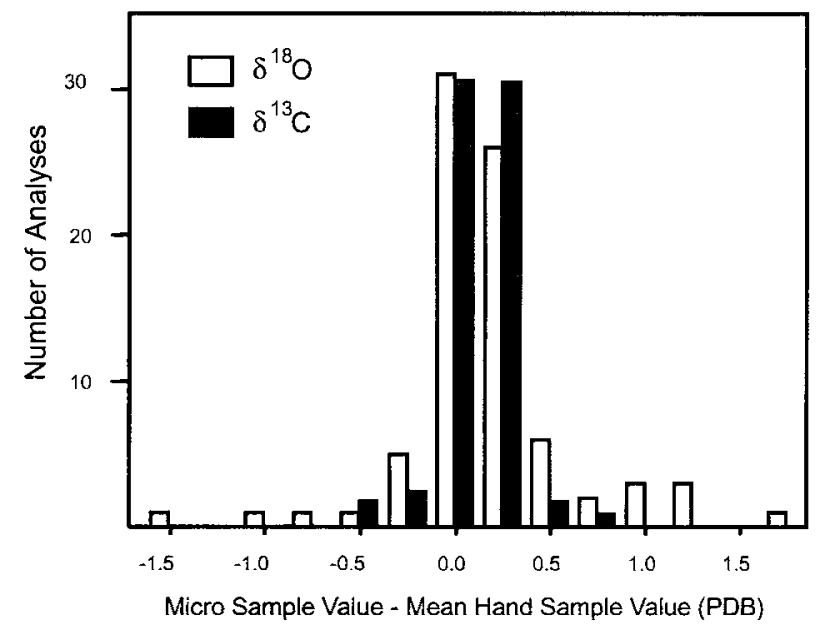

Fig. 4. Homogeneity of micrite isotopic composition within kilogram-sized hand samples of Peterson Limestone. This is a frequency plot of differences between microsample isotopic composition (\% PDB) and mean sample composition from multiple $\delta^{18} \mathrm{O}$ and $\delta^{13} \mathrm{C}$ analyses of 50 hand samples. Approximately $86 \%$ of all samples have a $\delta^{18} \mathrm{O}$ variance of less than $1 \%$, and $90 \%$ of all samples have a variance less than $0.5 \%$ in $\delta^{13} \mathrm{C}$.

compositions. Corrections for potential differences in the $\mathrm{CO}^{2} / \mathrm{CO}^{3=}$ acid fractionation between calcite and dolomite have been made by applying a $0 \cdot 8 \%$ correction (Sharma \& Clayton, 1965) normalized to the dolomite content of individual samples. Such a procedure possibly over-corrects for fractionation at $73^{\circ} \mathrm{C}$, a factor which should decrease with increasing temperature.

Carbonate stable isotopic compositions exhibit strong covariance between $\delta^{18} \mathrm{O}$ and $\delta^{13} \mathrm{C}$ (Fig. 5), with $\delta^{18} \mathrm{O}$ ranging from about $-13 \%$ (PDB) to $-3 \%$ (PDB) and $\delta^{13} \mathrm{C}$ ranging from $-5 \%$ (PDB) to $-2 \%$ (PDB). In addition, $\delta^{18} \mathrm{O}$ values linearly correlate with dolomite content in all stratigraphic sections (Fig. 6); calcitic limestone has the most ${ }^{18} \mathrm{O}$-depleted compositions and dolostone has the most ${ }^{18} \mathrm{O}$-enriched compositions.

Textural and compositional attributes of dolomite and calcite within lacustrine micrite from the Peterson Limestone indicate that these phases co-precipitated during early stabilization of precursor magnesian calcite carbonate mud in a largely closed diagenetic system (Drummond et al., 1993). Uniform difference in the isotopic compositions of these phases over the entire mineralogical range of whole-rock compositions reflects equilibrium partitioning of ${ }^{18} \mathrm{O}$ and ${ }^{13} \mathrm{C}$ between dolomite and calcite. Diagenetic dolomite is enriched in ${ }^{18} \mathrm{O}$ by $4.4 \%$ and in ${ }^{13} \mathrm{C}$ by $1.8 \%$ relative to coexisting calcite, values that are discernibly different from expected open-system 


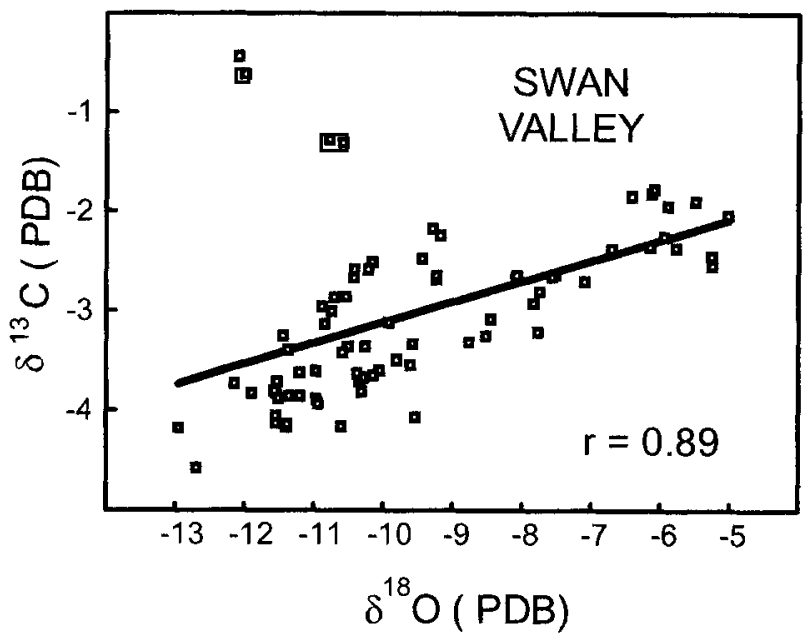

Fig. 5. Cross-plot of carbon and oxygen isotopic analyses of micritic limestones from the Swan Valley section (Fig. 2). Note the pronounced covariance between $\delta^{18} \mathrm{O}$ and $\delta^{13} \mathrm{C}(r=0 \cdot 89)$, a compositional pattern typical of arid-region lakes where carbonate precipitation and accumulation occurs in closed basins with relatively long residence times (Talbot, 1990). Outliers to the trend represent replicate analyses of two organic-rich limestone samples. Their extremely enriched carbon isotopic compositions possibly reflect organically derived methane-sourced carbon incorporation during diagenesis (e.g. Talbot \& Kelts, 1991).

mixing trends (Drummond et al., 1993). Both stable isotopic and major element chemistry is preserved within micritic carbonate samples and, as such, micrites retain direct records of variation in the composition of Cretaceous lakewater during accumulation of the Peterson Limestone.

Stratigraphic variation in geochemical parameters occurs at two scales. Dolomite and $\delta^{13} \mathrm{O}$ contents of lacustrine micrite units generally decrease progressively from the base to the top of each limestone bed (Fig. 7), while upsection through any individual stratigraphic section samples become more depleted in ${ }^{18} \mathrm{O}$.

\section{INTERPRETATION}

Given the presence of metre-scale micritic carbonate to argillaceous marl alternation within the Peterson Limestone, upsection lacustrine carbonate to fluvial clastic cyclicity at the formationscale, and strong correlation between stable isotopic and mineralogical compositions of lacustrine micrite, it is possible to interpret both metre-scale and formational lithological and geochemical transitions in a context of climatic rather than tectonic forcing.

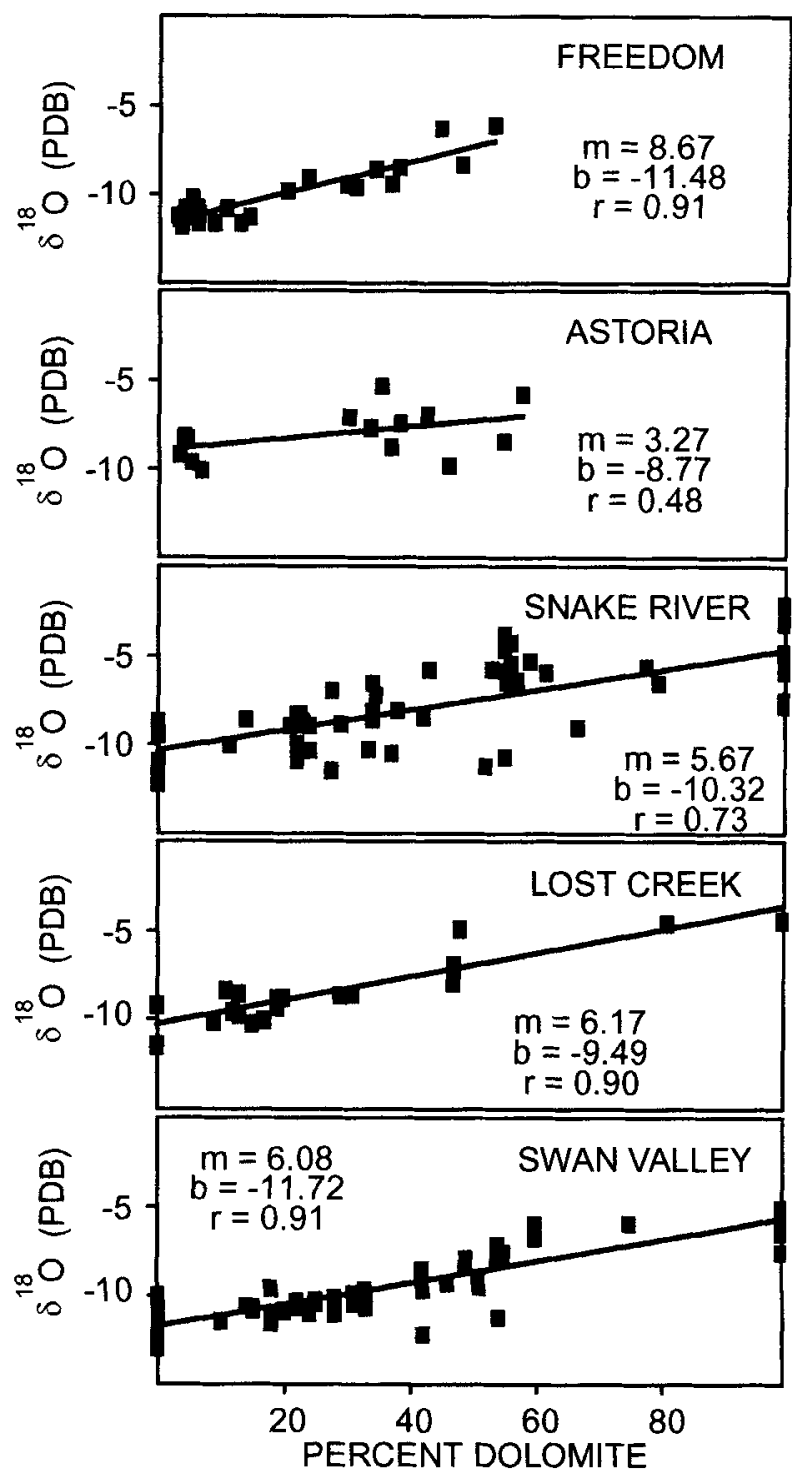

Fig. 6. Paired $\delta^{18} \mathrm{O}$ and dolomite contents of carbonate micrites from five Peterson Limestone stratigraphic sections (Fig. 2). Note that all sections exhibit similar slopes of compositional covariance ( $m=$ about 6 ), but with intercept values ranging from about -9.0 (Astoria) to -11.7 (Swan Valley). Similarity of slopes is interpreted as representing chemical $(\mathrm{Mg} / \mathrm{Ca})$ and isotopic evolution of the same body of water, while differences in intercept values $\left(\delta^{18} \mathrm{O}\right.$ value of pure calcite limestone in each section) possibly reflect the position of each stratigraphic section relative to inlets and outlets of water (e.g. Talbot, 1990). Note that sections with slopes differing from 6 do not contain pure dolostone end-members, indicating that slopes calculated for those sections may be inaccurate.

\section{Origins of dolomite}

It has long been recognized that the presence of dolomite in lacustrine sediment indicates evaporative evolution of lakewaters and attainment of 
Fig. 7. Oxygen isotopic composition, dolomite abundance and carbonate content within individual beds of Peterson Limestone. Limestones become more ${ }^{18} \mathrm{O}$-depleted, more calcitic and of greater purity upsection. In a similar manner, most individual beds (lightly shaded) exhibit abrupt and asymmetric compositional variations in which dolomite and ${ }^{18} \mathrm{O}$-enriched bases pass vertically into more calcitic and ${ }^{18} \mathrm{O}$-depleted tops (heavily shaded). These higher-frequency patterns of micritic limestone/marly shale alternation, as well as changes in limestone composition are interpreted to record short-term transitions from arid to humid climatic conditions superimposed on a similar formation-scale pattern of change manifest over tens of metres of stratigraphic section.

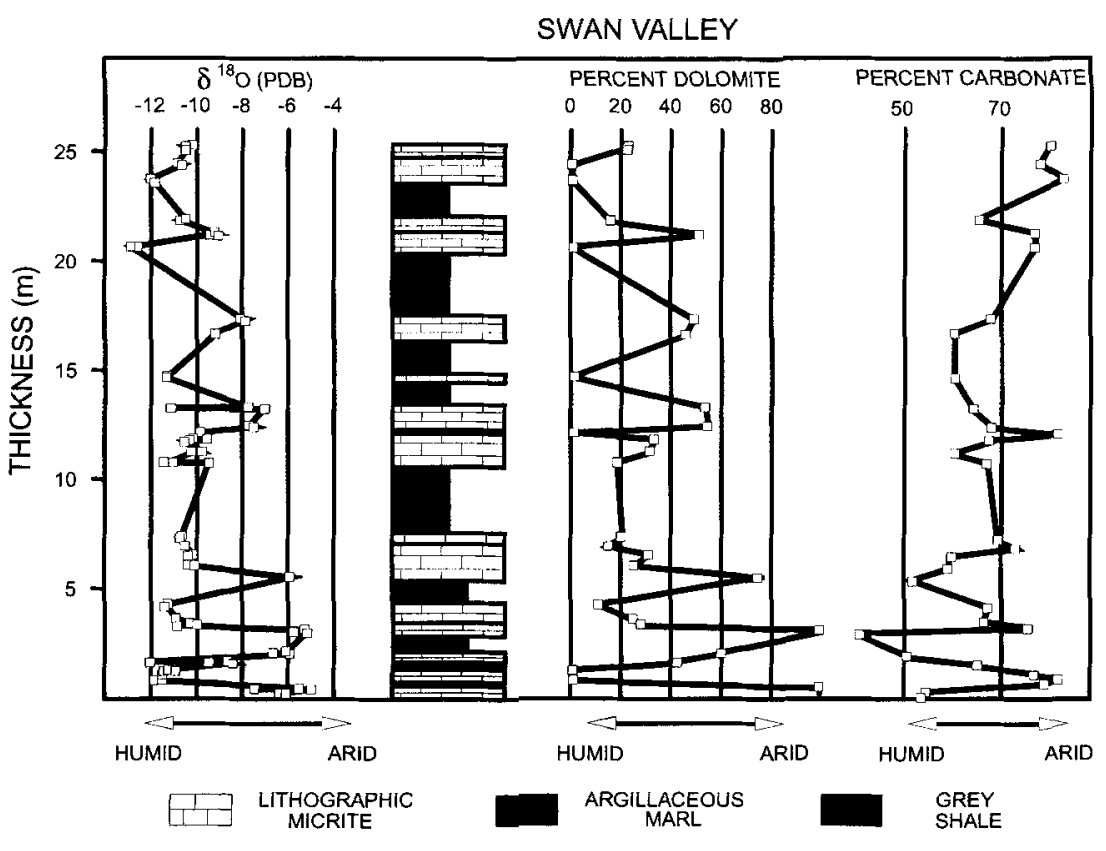

elevated Mg/Ca ratio (Hardie \& Eugster, 1970; Hardie et al., 1977; Eugster \& Hardie, 1978). Muller et al. (1972), for example, recognized modern and near-recent dolomite in a number of lake deposits to be the product of post-depositional diagenetic alteration of originally high-Mg calcite sediment through a process of dissolution of metastable high-Mg calcite and reprecipitation of thermodynamically stable dolomite and low-Mg calcite phases. Other studies have demonstrated that an elevated $\mathrm{Mg} / \mathrm{Ca}$ ratio and the presence of post-depositional diagenetic dolomite generally corresponds to periods of relatively arid conditions, as corroborated by other proxies of palaeoclimate such as positions of former shorelines, abundance of different pollen taxa and variation in the stable isotopic signature of autogenic phases (e.g. Muller \& Wagner, 1978)

Thus, the abundance of dolomite within Peterson limestone micrite is interpreted to be a proxy of lakewater $\mathrm{Mg} / \mathrm{Ca}$ ratio. More calcitic micrites record a regionally positive hydrological balance between precipitation and evaporation, resulting in the development of a large flux of fluvial waters from surrounding catchments into the lake basin, and establishment of a throughflowing, hydrologically open lake system. Conversely, increased dolomite abundance records climate change to more negative hydrologica 1 balances, progressive decrease in fluvial flux and chemical evolution of lakewaters to more saline conditions, coupled with an increase in lakewater $\mathrm{Mg} / \mathrm{Ca}$ through carbonate precipitation. The unusual distribution of dolomite abundance in the Peterson Limestone is additional evidence for the episodic development of evaporitic lakewaters (Fig. 3). Dolomite contents from 0 to $60 \%$ of total carbonate (a range encompassing most Peterson Limestone samples) originated during the in-situ stabilization of precursor $\mathrm{Mg}$ calcite (Drummond et al., 1993) with compositions that ranged from pure calcite to calcites with a composition of about $\mathrm{Ca}_{0.7} \mathrm{Mg}_{0.3}$. Those stratigraphic intervals containing pure dolomicrite probably represent development of extremely evaporitic lakewater and the atypical precipitation of dolomite as the primary sedimentary carbonate phase. The fact that pure dolostone is rare compared with dolomite-calcite mixtures indicates that such extremely evaporitic conditions were infrequently achieved.

\section{Carbonate stable isotopic compositions}

Carbon and oxygen stable isotopic composition of primary lacustrine carbonate has been used extensively as a direct indicator of changes in climate during sediment deposition (Stuiver, 1970; Fritz et al., 1975; Schoell, 1978; Stiller \& Kaufman, 1985; Kelts \& Talbot, 1986; McKenzie \& Eberli, 1987; Suchecki et al., 1988; Kelts \& Talbot, 1989; Talbot, 1990; Drummond, 1995). While completely unequivocal evidence that lacustrine carbonate forms in isotopic equilibrium with lakewater has yet to be produced, some studies have suggested this to be true (Turner et al., 1983; 
McKenzie, 1985; Gasse \& Fontes, 1987; Fritz et al., 1987).

The assumption that carbonate forms in equilibrium with lakewater (or that the magnitude of the disequilibrium is nearly constant) allows for a direct evaluation of changes in carbonate isotopic composition in terms of inferred hydrological fluxes. The most ${ }^{18} \mathrm{O}$-depleted samples probably represent completely open hydrological conditions with through-flow dominating over surface evaporation, while ${ }^{18} \mathrm{O}$-enriched samples represent progressive lake closure and isotopic evolution (Fig. 7). This process of evaporative enrichment of lakewater in ${ }^{18} \mathrm{O}$ is well understood (Fontes \& Gonfiantini, 1967; Gat \& Gonfiantini, 1981; Gonfiantini, 1986; Fritz et al., 1987), and has been documented in a number of modern evaporative lake systems (Schoell, 1978; Spencer et al., 1984; McKenzie, 1985; Talbot \& Kelts, 1986; Hillaire-Marcel \& Casanova, 1987; Halfman et al., 1989).

Conversely, a complete understanding of the carbon isotopic budget of carbonate producing lakes has not as yet been achieved. For some modern systems, carbonate $\delta^{13} \mathrm{C}$ has been shown to be directly related to relative rates of biologically mediated production of reduced organic carbon and subsequent oxidation of that organic carbon in the water column (McKenzie, 1985). Although this mechanism dominates in eutrophic and hypereutrophic lake systems, large changes in carbonate $\delta^{13} \mathrm{C}$ in generally oligotrophic aridregion lakes is thought to be controlled by isotopic partitioning during $\mathrm{CO}_{2}$ outgassing (Talbot \& Kelts, 1991). Therefore, direct coupling between carbonate $\delta^{18} \mathrm{O}$ and $\delta^{13} \mathrm{C}$ (Fig. 5) is generally considered typical of evaporitic systems (Talbot, 1990; Talbot \& Kelts, 1991).

\section{Isotopic-mineralogical covariance}

Isotopic and mineralogical data describe strong positive linear covariance between $\delta^{18} \mathrm{O}$ and percentage dolomite in all stratigraphic sections. Talbot (1990) has noted that paired $\delta^{18} \mathrm{O}$ and $\delta^{13} \mathrm{C}$ data from other lacustrine carbonate sequences commonly describe slopes of isotopic covariance similar to those seen in sections of the Peterson Limestone (Fig. 5), and has argued that these trends record isotopic evolution of lakewater under conditions of increasing evaporation. Because increased rate of evaporation relative to freshwater flux should influence lakewater $\mathrm{Mg} / \mathrm{Ca}$ ratio as well as isotopic composition, we interpret slopes of $\delta^{18} \mathrm{O}$ and percentage dolomite co- variance (Fig. 7) to indicate coupled mineralogical and isotopic evolution of sediment generated within each stratigraphic section.

Talbot (1990) interprets the compositional position of any individual sample along such paired $\delta^{18} \mathrm{O}$ and $\delta^{13} \mathrm{C}$ trends to reflect the degree of evaporative evolution experienced by the lakewater in which that carbonate was precipitated, an evolution that in theory could proceed through time with progressive basin closure, or in space as water moves via axial flow within an arid-region lake (Muller \& Wagner, 1978). Differences in calcitic end-member isotopic compositions ( $y$ intercepts of compositional covariance; Fig. 6) could reflect the location of individual stratigraphic sections relative to inlets and outlets of Lake Peterson and/or regional variation in the isotopic composition of inflowing meteoric fluids. Regional variation of $\delta^{18} \mathrm{O}$ intercept values from the sections along the western Sevier orogen (Freedom, Idaho; -11.48), to the lake centre sections (Snake River, Wyoming, - 10.32), to sections along the eastern cratonward lake margin (Astoria, Wyoming; - 8.77), do suggest a predominance of more depleted inflow, presumably from higher western source regions, and indicate that even under hydrologically open conditions such as must have existed during calcitic micrite accumulation, some isotopic variation probably did occur within the lake basin. However, error in the estimation of the $y$-intercept associated with this regression analysis decreases the absolute amount of supposed intralake isotopic variation (Fig. 6). It should be noted that the possibility exists that variation in intercept values represents the isotopic evolution of a number of lakes arranged in series. However, little or no other evidence exists to support this hypothesis. Indeed, isopach data support the presence of only a single lake basin (Fig. 2).

\section{Implications for climate change}

Perhaps one of the most significant observations to be drawn from distributions of mineralogical and isotopic variation in the Peterson Limestone is that upsection transitions from more carbonaterich to more clastic-rich lithologies are accompanied by a progressive decrease in dolomite abundance and depletion in ${ }^{18} \mathrm{O}$. This pattern is repeated both at a scale of individual micrite beds and at a formational scale between the lacustrine Peterson Limestone and the overlying fluvial Bechler Formation. At both scales of consideration, more dolomitic and ${ }^{18} \mathrm{O}$-enriched intervals 
commonly occur at the base, with progressive depletion in ${ }^{18} \mathrm{O}$ content and decreasing dolomite abundance upsection (Fig. 7).

Metre-scale observations show that most limestone beds exhibit asymmetric patterns of mineralogical and isotopic variation. Initially ${ }^{18} \mathrm{O}$-enriched dolomitic layers record accumulation under hydrologically closed arid conditions that change upsection into ${ }^{18} \mathrm{O}$-depleted calcitic layers recording carbonate accumulation in open lake systems before evolving to settings in which deposition was dominated by the accumulation of clastic material.

These patterns indicate that carbonate deposition was initiated during relatively evaporative periods when fluvial inflow and clastic flux were at a minimum, and when rates of tectonic subsidence were able to outstrip rates of sediment accumulation. With time, regional rates of precipitation gradually increased relative to mean evaporation and fluvial flux into and through the lake basin. During intervals of increased meteoric precipitation, the net effect of lake-surface evaporation and lakewater ${ }^{18} \mathrm{O}$ enrichment diminished to the point that lakewater $\delta^{18} \mathrm{O}$ approached the mean isotopic composition of regional meteoric water, while ionic strength and $\mathrm{Mg} / \mathrm{Ca}$ ratio of lakewater decreased.

Metre-scale intraformational variation in $\delta^{18} \mathrm{O}$ (Fig. 7) probably records episodic evaporation and lakewater enrichment from a relatively constant meteoric fluid-derived calcite with $\delta^{18} \mathrm{O}$ around $-13 \%$ (PDB), followed by a return to more humid conditions and lakewater depletion in ${ }^{18} \mathrm{O}$. Increased meteoric inflow was accompanied by a greater flux of allochthonous argillaceous sediment, manifest as generally abrupt transitions from pure carbonate accumulation to the formation of more shale-rich beds.

Formation-scale transitions from fluvial to lacustrine to fluvial deposition within the Gannett Group are also accompanied by changes in mineralogy and isotopic composition of lacustrine limestone (Fig. 7). These trends suggest that longterm changes in climate also served to control the flux of water and fluvial sediment to the subsiding foreland basin. If observed cyclicity of fluvial to lacustrine accumulation was related to climate, only one hemicycle (arid to humid) is recorded by lacustrine carbonate (Fig. 8).

\section{Cyclicity, tectonics, climate}

Gannett Group lithological variation occurs at scales of both fluvial-to-lacustrine and micritic

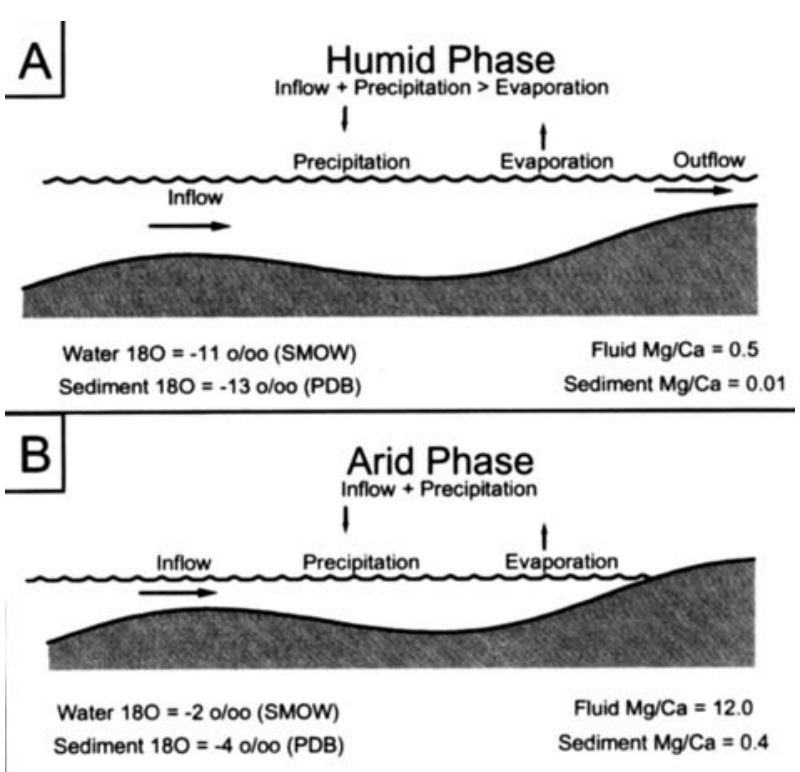

Fig. 8. Conceptual model of arid and humid phase carbonate deposition. (A) During humid phases, rates of inflow and precipitation exceeded rates of evaporation, producing a hydrologically open system. Lake water isotopic composition most closely reflected meteoric water composition ( $-11 \%$ SMOW) and carbonate precipitated from the lakewater was at its most ${ }^{18} \mathrm{O}$-depleted value ( $-13 \%$ PDB). Likewise, lakewater $\mathrm{Mg} / \mathrm{Ca}$ ratio was close to the riverine value, and low $-\mathrm{Mg}$ calcite was precipitated. (B) During arid phases, inflow and surface precipitation was equal to or less than evaporation, and a hydrologically closed lake system developed. Lake water underwent evaporative enrichment in ${ }^{18} \mathrm{O}$, which was reflected in the composition of carbonate sediment. Continued precipitation of calcium carbonate in the closed lake system led to progressive increase in the $\mathrm{Mg} / \mathrm{Ca}$ ratio of lakewater, which in turn gave rise to deposition of progressively more Mg-rich carbonate sediment until autogenic dolomite was precipitated.

limestone-to-shaly micrite transitions. The total duration of continental foreland basin deposition in western Wyoming and eastern Idaho is poorly constrained, and it is therefore difficult to precisely calculate cycle period at either scale. Based on contained freshwater fauna, available data indicate that the Gannett Group deposition occurred during the early Cretaceous. Peck (1957) suggested that Ephraim Conglomerate deposition occurred from the Berriasian through the Barremian, while the Peterson, Bechler and Draney Formations accumulated during the Aptian.

In this context, the lacustrine-fluviallacustrine sequence that comprises the Peterson, Bechler and Draney Formations has a depositional duration of about $6 \mathrm{Myr}$ (e.g. Palmer, 
1983). If sedimentation rates in the Peterson and Draney lake systems were similar, and if fluvial deposition of the Bechler sandstone was about an order of magnitude greater (e.g. Sadler, 1981), stratigraphic data on the Gannett Group indicate that basin axis accumulation occurred over about 2.0 Myr for the Peterson Limestone, about 0.7 Myr for the Bechler formation and over about 3.3 Myr for the Draney Limestone. Because lithological and geochemical variations in Peterson Limestone sections indicate that lacustrine deposition occurred during half of one long-term arid-tohumid cycle, formation-scale fluvial-lacustrine cyclicity therefore has an apparent period of some 3-4 Myr.

Because abundance of intraformational variation is dependent on the location of measured sections relative to the basin centre, estimation of durations of micrite to marly micrite couplets is even less certain. However, given the abundance of such couplets in lake-centre sections, shortterm cycle period is probably on the order of several hundred thousand years.

The occurrence of lithological cyclicity occurring with a periodicity of several hundred thousand years is commonly cited as evidence of Milankovitch-band Earth-orbital control on regional climate and sediment accumulation (e.g. Arthur et al., 1985; Hattin, 1985; Sageman, 1985). We have no compelling evidence within the Peterson Limestone to indicate that Milankovitchband cycles are present. However, the presence of lithological cyclicity alone need not be linearly related to change in extrabasinal variables such as climate. Regular alternation of micrite and shaly micrite in the Peterson Limestone, and the abrupt nature of many carbonate to clastic transitions both within and between formations, possibly record attainment of climatic thresholds that served to separate relatively arid from relatively humid conditions. Synoptic-scale computational modelling of lake-atmosphere hydrological feedbacks by Hostetler et al. (1994) indicate that sufficiently large lakes may become hydrologically self-sustaining due to large-scale recycling of meteoric water. As lake area grows in response to changing climate, patterns of regional rain fall may shift from highland only to basin-wide precipitation, providing renewed abundant flux of terrigenous material to lake-centre settings. Conversely, decrease in lake area in response to regional drying would result in significantly less intrabasinal cycling of meteoric water, reduction in rates of basin-wide precipitation, and the rapid attainment of extremely evaporitic conditions, such as the transition from Tertiary Lake Bonneville to Quaternary Great Salt Lake deposition.

In a somewhat similar vein, data on the mineralogy and composition of Peterson Limestone micrites clearly implicate secular variation in the intensity of lake basin evaporation and precipitation at a comparable scale to that manifest as fluvial-lacustrine cyclicity. Although this suggests significant climate change occurred during development of individual foreland systems, correlation alone does not negate the possibility of some genetic link between intensity of foreland basin tectonism, elevation of the Sevier orogen and subsidence rate of the adjacent foreland basin.

Subsidence could have played an important role in determining differences between elevation of lake outlets and the lake basin centre, which in turn could directly influence lake area and potentially regional rates of lakewater cycling. More intense tectonism would serve to mediate climatic variation and drive the onset of regional aridity. Similarly, uplift alone could have increased the role of the western Sevier orogen as an elevated barrier to the influx of extrabasinal atmospheric moisture. More intense tectonism in this case would serve to intensify the orogenic rain shadow and bolster the onset of regional aridity.

Based on compositional variation in the Peterson Limestone, it is apparent that intraformational and interformational lithological variation is not simply related to foreland tectonism and changes in amounts of relative relief between orogens and adjacent lake basin or fluvial plains; rather, the Gannett Group provides a striking example of lithological cyclicity within a foreland basin controlled not solely by episodic tectonism but rather by either associated or unrelated changes in regional climate.

\section{CONCLUSIONS}

Combined lithological, mineralogical and isotopic data from the lower Cretaceous Peterson Limestone indicate that cyclical transitions from carbonate-rich to terrigenous-rich intervals occurred at two scales, and that both relate to secular variation in rates of regional meteoric precipitation relative to rates of evaporation across the Sevier orogen. Asymmetric patterns in $\delta^{18} \mathrm{O}$ and dolomite abundance within individual limestone beds demonstrate that accumulation of 
lacustrine carbonate occurred more or less continuously during arid-to-humid transitions, but that either those transitions occurred abruptly or rates of sediment accumulation slowed dramatically during the onset of more arid conditions, possibly in response to the presence of hydrological thresholds within the lakeatmosphere feedback cycle. Carbonate deposition began during intervals of maximum aridity, and decreased with increased rainfall and decreased evaporation until minimum aridity resulted in greater fluvial flux of terrigenous sediment. When rate of carbonate generation was finally outpaced by clastic flux, fluvial systems of the Bechler Formation prograded across and along the basin axis. Such long-term trends suggest that fluviallacustrine cyclicity, at least during this portion of Cordilleran foreland basin deposition, was significantly influenced by early Cretaceous climatic change as well as changing rates of tectonism and uplift of the bounding orogen.

\section{ACKNOWLEDGMENTS}

During the course of this study, conversations with numerous colleagues at the University of Michigan and elsewhere have added greatly to our appreciation and understanding of lacustrine systems as storehouses of continental climate. Specifically we wish to thank Linda Albertzart, David Dettman, William Patterson, Brad Opdyke, James Walker and Kevin Given for helpful discussion and encouragement during this investigation. Early drafts of this manuscript benefited greatly from substantial reviews by Joseph Hughes, Tracy Frank, Judy McKenzie, Paul Olsen, Mike Talbot and Julian Andrews. Research on ancient lacustrine carbonates at the University of Michigan is supported by the National Science Foundation, NSF grant EAR-90-19095.

\section{REFERENCES}

Armstrong, F.C. (1968) Sevier orogenic belt in Nevada and Utah. Bull. geol. Soc. Am., 79, 429-458.

Armstrong, F.C. and Oriel, S.S. (1965) Tectonic development of Idaho-Wyoming thrust belt. Bull. Am. Ass. petrol. Geol., 49, 1847-1866.

Arthur, M.A. and Dean, W.E. (1991) A holistic geochemical approach to cyclomania-examples from Cretaceous pelagic limestone sequences, In: Cycles, Events, and Stratigraphy (Ed. by G. Ensele, W. Richen, and A. Seilacher), pp. 126-166. SpringerVerlag, New York.
Arthur, M.A., Dean, W.E. and Schlager, S.O. (1985) Variations in the global carbon cycle during the Cretaceous related to climate, volcanism, and changes in atmospheric $\mathrm{CO}_{2}$, In: The Carbon Cycle and Atmospheric $\mathrm{CO}_{2}$ : Natural Variations, Archean to Present (Ed. by E. T. Sundquist and W. S. Broecker), American Geophys. Union Monograph, 32, 504-529.

Barron, E.J., Arthur, M.A. and Kauffman, E.G. (1985) Cretaceous rhythmic bedding sequences - a plausible link between orbital variations and climate. Earth planet. Sci. Lett., 40, 103-133.

Beck, R.H. and Vondra, C.A. (1985) Orogeny and stratigraphy: numerical models of the Paleozoic in the eastern interior of North America. Tectonics, 7, $389-416$.

Blair, T.C. and Bilodeau, W.L. (1988) Development of tectonic cyclothems in rift, pull-apart, and foreland basins: sedimentary response to episodic tectonism. Geology, 16, 517-520.

Brown, R.E. and Wilkinson, B.H. (1981) The Draney Limestone: Early Cretaceous lacustrine carbonate deposition in western Wyoming and southeastern Idaho. Contrib. Geol., 20, 23-31.

Craig, H. (1957) Isotopic standards for carbon and oxygen and correction factors for mass spectrometric analysis of carbon dioxide. Geochim. Cosmochim. Acta, 12, 133-149.

Ditchfield, P. and Marshall, J.D. (1989) Isotopic variation in rhythmically bedded chalks. Paleotemperature variation in the Upper Cretaceous. Geology, 17, $842-845$.

Drummond, C.N., Patterson, W.P. and Walker, J.C.G. (1995) Climatic forcing of carbon-oxygen isotopic covariance in temperate-region marl lakes. Geology, 23, 1031-1034.

Drummond, C.N., Wilkinson, B.H. and Lohmann, K.C (1993) Rock-dominated diagenesis of lacustrine magnesian calcite micrite. Carbonates Evaporites, 8, 214-223.

Eisbacher, G.H., Carrigy, M.A. and Campbell, R.B. (1974) Paleodrainage pattern and late-orogenic basins of the Canadian Cordillera. In; Tectonics and Sedimentation (Ed. by W. R. Dickinson), Spec. Publ. Soc. econ. Paleont. Miner., 22, 143-166.

Eugster, H.P. and Hardie, L.A. (1978) Saline Lakes. In Lakes: Chemistry, Geology, Physics (Ed. by A. Lerman), pp. 237-393. Springer-Verlag, New York.

Eyer, J.A. (1964) Stratigraphy and micropaleontology of the Gannett Group of western Wyoming and southeastern Idaho. PhD thesis, University of Colorado.

Eyer, J.A. (1969) Gannett Group of western Wyoming and southeastern Idaho. Bull. Am. Ass. petrol. Geol., 53, 1368-1390.

Fischer, A.G. and Schwarzacher, W. (1984) Cretaceous bedding rhythms under orbital control? In: Milankovitch and Climate, Part I (Ed. by A. L. Berger et al.), pp. 163-175. Reidel, New York.

Flemings, P.B. and Jordan, T.E. (1990) Stratigraphic modeling of foreland basins: interpreting thrust deformation and lithosphere rheology. Geology, 18, $430-434$. 
Fontes, J.C. and Gonfiantini, R. (1967) Comportement isotopique au cours de l'evaporation de deux basins sahariens. Earth planet. Sci. Lett., 3, 258-266.

Fritz, P., Anderson, T.W. and Lewis, C.F.M. (1975) LateQuaternary climatic trends and history of Lake Erie from stable isotope studies. Science, 190, 267-269.

Fritz, P., Morgan, V., Eicher, U. and McAndres, J.H. (1987) Stable isotope, fossil coleoptera and pollen stratigraphy in Late Quaternary sediments from Ontario and New York State. Palaeogeogr., Palaeoclim., Palaeoecol., 58, 183-202.

Gasse, F. and Fontes, J.C. (1987) Palaeoenvironments and palaeohydrology of a tropical closed lake (Lake Asal, Djibouti) since 10000 year B.P. Palaeogeogr. Palaeoclim., Palaeoecol., 69, 67-102.

Gat, J.R. and Gonfiantini, R. (1981) Stable isotope hydrology of deuterium and oxygen-18 in the water cycle. International Atomic Energy Agency, Tech. Rep. Series, 210.

Glass, S.W. and Wilkinson, B.H. (1980) The Peterson Limestone - Early Cretaceous lacustrine carbonate deposition in western Wyoming and southeastern Idaho. Sediment. Geol., 27, 143-160.

Goldsmith, J.R., Graf, D.L. and Heard, H.C. (1961) Lattice constants of the calcium-magnesium carbonates. Am. Miner., 46, 453-457.

Gonfiantini, R. (1986) Environmental isotopes in lake studies. In: Handbook of Environmental Isotope Geochemistry (Ed. by P. Fritz and J. C. Fontes), pp. 133-168. Elsevier, New York.

Halfman, J.D., Johnson, T.C., Showers, W.J. and Lister, G.S. (1989) Autogenic low-Mg calcite in Lake Turkana, Kenya. J. African Earth Sci., 8, 533-540.

Hardie, L.A. and Eugster, H.P. (1970) The evolution of closed-basin brines. Spec. Publ. Miner. Soc. Am., 3, 273-290.

Hardie, L.A., Smoot, J.P. and Eugster, H.P. (1977) Saline lakes and their deposits: a sedimentological approach. Spec. Publ. int. Ass. Sediment., 2, 7-41.

Hattin, D.E. (1985) Distribution and significance of widespread, time-parallel pelagic limestone bEd. by in Greenhorn Limestone (Upper Cretaceous) of the central Great Plains and southern Rocky Mountains. In: Fine-grained Deposits and Biofacies of the Cretaceous Western Interior Seaway: Evidence for Cyclic Sedimentary Processes (Ed. by L. M. Pratt et al.), SEPM Fieldtrip Guidebook, 4, 28-37.

Heller, P.L., Angevine, C.L., Winslow, N.S. and Paola, C. (1988) Two-phase stratigraphic model of forelandbasin sequences. Geology, 16, 501-504.

Hillaire-Marcel, C. and Casanova, J. (1987) Isotopic hydrology and paleohydrology of the Magadi (Kenya)-Natron (Tanzania) basin during the Late Quaternary. Palaeogeogr. Palaeoclim. Palaeoecol., 58, 155-181.

Holm, M.R., James, W.C. and Suttner, L.J. (1977) Comparison of the Peterson and Draney Limestone, Idaho and Wyoming, and the calcareous members of the Kootenai Formation, western Montana. TwentyNinth Annul. Field Conf. Wyoming Geological Assoc. Guidebook, pp. 259-270. Wyoming Geological Association.
Hopkins, J.C. (1985) Channel-fill deposits formed by aggradation in deeply scoured, superimposed distributaries of the lower Kootenai Formation (Cretaceous). J. sedim. Petrol., 55, 42-52.

Hostetler, S.W., Giorgi, F., Bates, G.T. and Bartlein, P.J. (1994) Lake-atmosphere feedbacks associated with paleolakes Bonneville and Lahontan. Science, 263, 665-668.

Kelts, K. and Talbot, M.R. (1986) Evidence for environmental change from stable isotopic signals in lacustrine carbonates: the Quaternary record from Lake Bosumtwi, Ghana. In: INQUA Symp. 'Changements globvaux en Afrique' (Ed. by H. Faure), pp. 181-184. Dakar.

Kelts, K. and Talbot, M.R. (1989) Lacustrine carbonates as geochemical archives of environmental change and biotic-abiotic interactions. In: Ecological Structure and Function in Large Lakes (Ed. by M. M. Tilzer and C. Serruya), pp. 290-317. Science and Technology Publishers, Madison, WI.

Kirkland, J.I. (1991) Lithostratigraphic and stratigraphic framework for the Mancos Shale (late Cenomanian to middle Turronian) of Black Mesa, northeastern Arizona. In: Stratigraphy, Depositional Environments, and Sedimentary Tectonics of the Western Margin, Cretaceous Western Interior Seaway (Ed. by J. D. Nations and J. G. Eaton), Spec. Pap. geol. Soc. Am., 260, 85-112.

Kominz, M.A. and Bond, G.C. (1990) A new method for testing periodicity in cyclic sediments: application to the Newark Supergroup. Earth planet. Sci. Lett., 98, 233-244.

Kominz, M.A., Bond, G.C., Beavan, J. and McManus, J. (1991) Are cyclic sediments periodic? Gamma analysis and spectral analysis of Newark Supergroup lacustrine strata. In: Sedimentary Modeling: Computer Simulations and Methods for Improved Parametre Definition (Ed. by K. Franseen et al.), Bull. Kansas geol. Surv., 233, 319-334.

Mansfield, G.R. (1927) Geography, geology, and mineral resources of southeastern Idaho. Prof. Paper U.S. Geol. Surv., 152.

Mansfield, G.R. (1952) Geography, geology, and mineral resources of the Ammon and Paradise quadrangles, Idaho. Prof. Paper U.S. Geol. Surv., 238.

McKenzie, J.A. (1985) Carbon isotopes and productivity in the lacustrine and marine environment. In: Chemical Processes in Lakes (Ed. by W. Stumm), pp. 99118. Wiley, New York.

McKenzie, J.A. and Eberli, G.P. (1987) Indications for abrupt Holocene climate change - Late Holocene oxygen isotope stratigraphy of the Great Salt Lake, Utah. In: Abrupt Climatic Change - Evidence and Implications NATO Advanced Study Institutes Series $C$ (Ed. by W. H. Berger and L. D. Labeyrei), pp. 127136.

Muller, G., Irion, G. and Forstner, U. (1972) Formation and diagenesis of inorganic $\mathrm{Ca}-\mathrm{Mg}$ carbonates in the lacustrine environment. Naturwissenchaften, 59, 158-164.

Muller, G. and Wagner, F. (1978) Holocene carbonate evolution in Lake Balaton (Hungary) - A response to 
climate and impact of man. Spec. Publ. int. Ass. Sedimentol., 2, 57-81.

Olsen, P.E. (1986) A 40-Million year lake record of early Mesozoic orbital climatic forcing. Science, 234, 842848.

Palmer, A.R. (1983) The decade of North American Geology 1983 geologic time scale. Geology, 2, 503504.

Park, J. and Oglesby, R.J. (1991) Milankovitch rhythms in the Cretaceous: A GCM modeling study. Palaeogeogr. Palaeoclim. Palaeoecol., 90, 329-355.

Peck, R.E. (1957) North American Mesozoic charophyta. Prof. Pap. U.S. geol. Surv,, 294-A.

Peck, R.E. and Craig, W.W. (1962) Lower Cretaceous nonmarine ostracodes and charophytes of Wyoming and adjacent area. Eleventh Annul. Field Conf. Wyoming Geological Assoc. Guidebook, 33-43.

Platt, N.H. (1989) Lacustrine carbonates and pedogenesis: sedimentology and origin of palustrine deposits from the Early Cretaceous Rupelo Formation, W. Cameros Basin, N. Spain. Sedimentology, 36, 665684.

Pratt, L.M. (1984) Influence of paleoenvironmental factors on preservation of organic matter in Middle Cretaceous Greenhorn Formation, Pueblo, Colorado. Bull. Am. Ass. petrol. Geol., 68, 1146-1159.

Sadler, P.M. (1981) Sediment accumulation rates and the completeness of stratigraphic sections. J. Geol, 89, 569-584.

Sageman, B.B. (1985) High-resolution stratigraphy and paleobiology of the Hartland Shale Member: analysis of an oxygen deficient epicontinental sea. In: FineGrained Deposits and Biofacies of the Cretaceous Western Interior Seaway: Evidence for Cyclic Sedimentary Processes (Ed. by L. M Pratt et al.), SEPM Fieldtrip Guidebook, 4, 110-121.

Schoell, M. (1978) Stable isotope analyses on autogenic carbonates from Lake Van sediments and their possible bearing on the climate of the past 10000 years. In: The Geology of Lake Van (Ed. by E. T. Degens and F. Kurtman), pp. 92-97. M.T.A. Press, Ankara.

Sethi, P.S. and Leithold, E.L. (1994) Climatic cyclicity and terrigenous sediment influx to the early Turonian Greenhorn sea, southern Utah. J. sedim. Petrol., B64, 26-39.

Sharma, T. and Clayton, R.N. (1965) Measurement of $\mathrm{O}^{18} / \mathrm{O}^{16}$ ratios of total oxygen of carbonates. Geochim. Cosmochim. Acta, 29, 1347-1353.

Spencer, R.J., Baedecker, M.J., Eugster, H.P., Forester, R.M., Goldhaber, M.B., Jones, B.F., Kelts, K.,
Climatic control of fluvial-lacustrine cyclicity 689

McKenzie, J.A., Madsen, D.B., Rettig, S.L., Rubin, M. and Bowser, C.J. (1984) Great Salt Lake, and Precursors, Utah - The last 30000 years. Contrib. Min. Petrol., 86, 321-334.

Stiller, M. and Kaufman, A. (1985) Paleoclimatic trends revealed by the isotopic composition of carbonates in Lake Kinneret. Z. Gletscherkd. Glazalgeol., 21, 79-87.

Stokes, W.L. (1952) Lower Cretaceous in Colorado Plateau. Bull. Am. Ass. petrol. Geol., 36, 1766-1776.

Stuiver, M. (1970) Oxygen and carbon isotope ratios of fresh-water carbonates as climatic indicators. $J$. geophys. Res., 75, 5247-5257.

Suchecki, R.K., Huber, J.F. and Birney De Wet, C.C. (1988) Isotopic imprint of climate and hydrochemistry on terrestrial strata of the Triassic-Jurassic Hartford and Fundy rift basins. J. sedim. Petrol., 58, 801-811.

Suttner, L.J. (1969) Stratigraphic and petrographic analysis of Upper Jurassic-Lower Cretaceous Morrison and Kootenai Formations, southwest Montana. Bull. Am. Ass. petrol. Geol., 53, 1391-1410.

Talbot, M.R. (1990) A review of the palaeohydrological interpretation of carbon and oxygen isotopic ratios in primary lacustrine carbonates. Chem. Geol. (Isotope Geoscience Section), 80, 261-279.

Talbot, M.R. and Kelts, K. (1986) Primary and diagenetic carbonates in the anoxic sediments of Lake Bosumtwi, Ghana. Geology, 14, 912-916.

Talbot, M.R. and Kelts, K. (1991) Paleolimnological signatures from carbon and oxygen isotopic ratios in carbonates from organic carbon-rich lacustrine sediments. In: Lacustrine Basin Exploration (Ed. by B. J. Katz), Mem. Am. Ass. petrol. Geol., 50, 99-112.

Turner, J.V., Fritz, P., Karrow, P.F. and Warner, B.G. (1983) Isotopic and geochemical composition of marl lake waters and implications for radiocarbon dating of marl lake sediments. Can. J. Earth Sci., 20, 599-615.

Wanless, H.B., Belknap, R.L. and Foster, H. (1955) Paleozoic and Mesozoic rocks of Gros Ventre, Teton, Hoback, and Snake River Ranges, Wyoming. Mem. geol. Soc. Am., 63.

Wiltschko, D.V. and Dorr, J.A. (1983) Timing and deformation in Overthrust Belt and foreland of Idaho, Wyoming, and Utah. Bull. Am. Ass, petrol. Geol., 67, 1304-1322.

Manuscript received 30 August 1995; revision accepted 11 January 1996. 